\title{
REPELLANCY EFFECT OF CERTAIN PLANT EXTRACTS AND OILS AGAINST HOUSE SPARROW BIRD AND HEAD INSECTS IN SORGHUM FIELDS.
}

\author{
El-Rawy, A.M. ${ }^{1}$ and A.E.A.A. Mourad ${ }^{2}$ \\ 1. Plant Protection Research Institute, ARC, Dokki, Giza, Egypt. \\ 2. Sorghum Department, Field Crops Research Institute, ARC, Giza, Egypt.
}

\begin{abstract}
The efficacy of seven plant extracts and five plant oils were tested as repellents to house sparrow bird, Passer domesticus niloticus and three head worms; Autoba (Eublemma) gayneri, Cryptoblabes gnidiella and Pyroderces simplex on Dorado variety under field conditions in Sids Agric. Res. Station, Beni-Sueif Governorate during 2005 and 2006 seasons. This work revealed that, the bird damage was generally clearly higher for grains during the mature stage (8.6$45.9 \%)$ than those of the dough stage $(2.1-8.2 \%)$. The plant extracts and oils caused a grain yield protection from the bird damage as 36.369.7 and $27.4-81.2 \%$ as well as, in the same time decreased the insect numbers with about $3.8-100.0 \%$ during the two considered stages, respectively. The plant extracts showed a higher efficiency against the sparrow bird in the mature than in dough stage, the vise was happened with the oils. Effects of the plant extracts differed according to the insect species. In this respect, cumin WE was the best against all insects, depressed their populations, in general, with about 42.0-79.1 and $68.4-100 \%$ in the two years, respectively. On the other side, the lowest efficiency was from wormwood AE (26.7- 34.0\% decrease) and lupine WE (6.9-29.7\%) in the first and second seasons, respectively. While the neemix oil, was relatively the strongest in the first year, depressed the insect population with about $38.7-54.9 \%$, the Olupine oil was the strongest in the second season $(35.1-81.3 \%)$. Coriander oil showed the least effect, 3.8-53.2\% depression only.
\end{abstract}

Key words: House sparrow bird; Head insects; Sorghum; Plant extracts; Oils.

\section{INTRODUCTION}

Grain sorghum (Sorghum bicolor (L.) Moench) grows about 350 to 400 thousand feddans in Middle and Upper Egypt. The Sorghum productivity usually is not enough for local consumption. The Sorghum Research Department in Egypt gains to increase sorghum productivity through different means as increasing the area as well as average grain yield per unit (feddan) and in the same time decreasing the losses of important pests as birds, insects and others. To increase grain sorghum area and average grain yield ought to decrease bird and insect damage in the old and new lands. Recently, birds especially house sparrow, Passer domesticus niloticus become one of the most important problems to the field crops in Egypt and the world. Birds damage to cereal crops reaches up to $10 \%$ of the production in African countries (Bruggers and Ruell, 1981) and limit grain production from sorghum in Canada (Bullard and Elias, 1980). In Egypt, it causes 14.30 and $43.75 \%$ damage for mature grain sorghum in Menia El-Kamh and El-Salheya farm,

Fayoum J. Agric. Res. \& Dev., Vol.22, No.1, January, 2008 
Sharkia Gov., respectively (El-Deeb, 1990). In Georgia, it causes a loss on units untreated with 24000 bushel and $50000 \$$ loss (Buntin and All, 2001).

Sorghum heads attacked by three worms: christmas berry webworm, Cryptoblabes gnidiella Mill; pink corn worm, Pyroderces simplex Wlsm and, in recent years, semi-looper worm, Autoba (Eublemma) gayneri (Roth.) (Lepidoptera: Noctuidae) (EL-Rawy, 2004). In Georgia, the sorghum head worms caused yield loss on units untreated with 3000 bushel and $6000 \$$ loss while this figure was $13000 \$$ from cost of control for 1,300 acers total price loss from cost of control and damage was 19000\$. (Buntin and All, 2001).

Most of the recent researchs on bird control involved the development of chemical compounds for direct application to maturing grain (Fitzwater, 1982). Nevertheless, this method might not be acceptable due to its residual effect and environmental hazards to humans, livestock and other non-target species (Fellows, 1979). Few medical aromatic and wild plants, well known to farmers, still maintain these defensive compounds. Furthermore, these compounds which are the results of millions of years of development, are biodegradable could be a potential source of repellents, which might be exploited by man to protect cultivated crop without the undesirable side effects of synthetic chemicals (Crocker, 1990). Water extract of five aromatic plants were tested as repellents to house sparrows on rice (El-Sherbiny $\boldsymbol{e t}$ al., 1994). Odour repellents to females would be useful by receiving fewer eggs to suppress the insect population while the female attractants may be utilized for luring the ovipositing females to either uneconomic hosts or certain baits. In this respect, water extracts of thirteen aromatic plants were used for Sesamia cretica on maize (Awadallah et al., 1984), anothers for Chilo agamemnon and Hydrellia prosternalis on rice (Soliman and Bleih, 1995) and for sugar beet insects (Shalaby et al., 2005).

Therefore, the main goal of the present study is to test the repellency effect of some plant extracts and oils in reducing the damage of house sparrow bird and three head worms for sorghum crop under field conditions.

\section{MATERIALS AND METHODS}

A two -year field experiment was conducted during 2005 and 2006 seasons at Sids Agricultural Research Station, Beni-Sueif Governorate, to study the effect of certain plant extracts and oils in reducing the damage of both house sparrow bird and head worms to sorghum crop.

The experiment area was cultivated with Dorado variety on 16 June for both seasons. A randomized complete blocks design with eight treatments plus one untreated (control), three replicates for each were used in the first season. In the second season, 10 treatments plus control were used by the same way. Each plot consisted of four ridges, $4 \mathrm{~m}$ long and $60 \mathrm{~cm}$ apart with $20 \mathrm{~cm}$ between hills. Two untreated ridges were left between each two plots. All traditional cultural practices were done with no insecticidal applications until the harvest.

1. Plants used: Three plant species belonging to three families were chosen in the $1^{\text {st }}$ season; black pepper, cumin and wormwood. In the second season, four plant species belonging to another three families were used beside the previous plants; colocynth, coriander, fenugreek and lupine all are illustrated in Table (1).

Fayoum J. Agric. Res. \& Dev., Vol.22, No.1, January, 2008 
Table 1. Plants investigated.

\begin{tabular}{|c|c|c|c|c|}
\hline Family & $\begin{array}{c}\text { English } \\
\text { name }\end{array}$ & Latin name & $\begin{array}{c}\text { Tested } \\
\text { part }\end{array}$ & Source \\
\hline Piperaceae & Black pepper & Piper nigrum Linn. & Fruits & Aswan \\
Cucurbitaceae & Colocynth & Citrullus colocynthis_Linn.) & $"$ & $"$ \\
Apiaceae & Coriander & Coriandrum sativum Linn. & $"$ & $"$ \\
Apiaceae & Cumin & Cuminum cyminum Linn. & $"$ & $"$ \\
Leguminosae & Fenugreek & Trigonella foenum-gracecum Linn. & Seeds & $"$ \\
Leguminosae & Lupine & Lupinus termis Forsk & Whole plant & $"$ \\
Asteraceae & Wormwood & Artemisia absinthium Linn. & & \\
& & & &
\end{tabular}

2. Extraction procedures: In the first season, two solvents (acetone and water) were used with the three mentioned plants, while in the second season, water was only used. To prepare the acetonic extracts, a sample $(250 \mathrm{gm})$ of each plant was separately ground using a high-speed grinder then $500 \mathrm{ml}$ acetone were added and left for $24 \mathrm{hr}$. The mixture was then filtered and the filtrated was evaporated with a rotary evaporator at $50{ }^{\circ} \mathrm{C}$. The crude extract was weighed and adjusted by water to obtain $8 \%$ solution kept in a refrigerator until testing according to Freedman et al., 1979.

As for the water extracts, were prepared according to Ahmed (1983). $80 \mathrm{gm}$ of each plant were separately ground then soaked in water with total volume of one liter. The mixture, after $24 \mathrm{hr}$ was thoroughly filtered and adjusted, as previous, to obtain an $8 \%$ solution kept also in a refrigerator until use.

3. Oils used: Two plant oils were chosen in the $1^{\text {st }}$ season; Neemix as neem and Nat 1 as jojoba. In the second season, the three oils of coriander, lupine and wormwood were used plus SiSi-6 emulsifier at $0.3 \%$. These oils and their concentrations are illustrated in Table (2).

Table (2): Oils investigated.

\begin{tabular}{|c|c|c|c|c|c|c|}
\hline Family & $\begin{array}{l}\text { English } \\
\text { name }\end{array}$ & Latin name & $\begin{array}{l}\text { Trade } \\
\text { name }\end{array}$ & $\begin{array}{l}\text { Conc. and } \\
\text { formula }\end{array}$ & $\begin{array}{c}\text { Conc./10 } \\
0 \mathrm{ml} \\
\text { water } \\
\end{array}$ & Source \\
\hline Buxaceae & Jojaba & $\begin{array}{c}\text { Simmodsia_chinensis } \\
\text { (Clink) }\end{array}$ & Nat 1 & $96 \% \mathrm{EC}$ & $1.5 \mathrm{ml}$ & $\begin{array}{c}\text { Egyptian National oil } \\
\text { Co. }\end{array}$ \\
\hline Meliaceae & Neem & $\begin{array}{c}\text { Azadirachta_indica A } \\
\text { Juss }\end{array}$ & Neemix & $4.5 \% \mathrm{EC}$ & $1.5 \mathrm{ml}$ & $\begin{array}{c}\text { N M Agro Egypt Ltd. } \\
\text { Co. }\end{array}$ \\
\hline Apiaceae & Coriader & $\begin{array}{c}\text { Coriandrum_sativum } \\
\text { Linn. }\end{array}$ & -- & $100 \%$ & $4 \mathrm{ml}$ & Local market (Aswan). \\
\hline Leguminosae & Lupine & Lupineus termis Forsk & -- & $100 \%$ & $4 \mathrm{ml}$ & " " \\
\hline Asteraceae & Wormwood & $\begin{array}{l}\text { Artemisia absinthium } \\
\text { Linn. }\end{array}$ & -- & $100 \%$ & $4 \mathrm{ml}$ & " $\quad " \quad$ " \\
\hline
\end{tabular}

4. Field application: The spray of extracts and oils was run after 10 days from flowering date (about 50\% plant flowering) for heads and repeated after 15 days later. According to Martin and Jackson (1977), cereals with exposed seeds (sorghum and millet) may need two methiocarb treatments for

Fayoum J. Agric. Res. \& Dev., Vol.22, No.1, January, 2008 
extended protection if bird damage begins shortly after flowering, while shielded seeds (wheat, barley and rice) may need only one treatment.

5. Bird damage assessment: Bird damage assessment was considered treated and untreated dough and mature stages by the following methods:

In the dough stage (20 days from flowering), the percentage of damaged grains (PDG) was calculated by the equation of Manikowski and Billiet (1983) as follows:

$\mathrm{PDG}=100 \times \mathrm{NIH} \times \mathrm{NDG} / \mathrm{NG}$

Where:

$\mathrm{NIH}=$ Number of infested heads in the plot.

$\mathrm{NDG}=$ Average number of damaged grains/infested head in the plot.

$\mathrm{NG}=$ Average number of total grains in the plot.

In the mature stage ( 45 days from flowering), the percentage of infested heads $(\mathrm{PIH})$ is equal to:

$\mathrm{PIH}=\mathrm{NIH} \times 100 /(\mathrm{NIH}+\mathrm{NUH})$.

Where:

$\mathrm{NUH}=$ number of uninfested heads.

The percentage of damaged grains (PDG) in the mature stage (45 days from flowering) was calculated according to Manikowski and Treca, 1982 as follows:

$\mathrm{PDG}=(\mathrm{WUH}-\mathrm{WIH}) \times 100 /(\mathrm{WUH}-\mathrm{WRGH})$

Where:

WUH $=$ average weight of uninfested heads.

WIH $=$ average weight of infested heads

WRGH= average weight of removed grain heads.

Protection index (PI) in the dough and mature stages, was calculated by the equation of Inglis and Isaacson (1987) as follows:

Protection Index $(\mathrm{PI})=(\mathrm{A}-\mathrm{B}) / \mathrm{A}$.

Where:

$\mathrm{A}=$ percentage of damaged grains in control.

$\mathrm{B}=$ percentage of damaged grains in treatment.

Number of head worms: A sample of ten heads/plot was randomly taken from the treated and untreated plots during the soft dough stage ( 23 days from flowering) and also during the hard dough stage (30 days from flowering). All larvae and pupae of semi looper worm, A. gayneri; christmas berry webworm, $C$. gnidiella Mill and pink corn worm, $P$. simplex Wlsm were counted in each sample.

6. Data analysis: Experimental data statistically analyzed according to Snedecor and Cochran (1981). Treatment means were compared by least significant difference (LSD) at $5 \%$ level of probability.

\section{RESULTS AND DISCUSSION}

\section{House sparrow bird:}

Data in Tables (3 and 4) show that, all plant extracts and oils in the two seasons (2005 and 2006) reduced the bird damage with different degrees depending on the type of extract and oil.

The data also show that, in the first season, the plant extracts were generally more effective against the house sparrow bird than the oils used. While the

Fayoum J. Agric. Res. \& Dev., Vol.22, No.1, January, 2008 
damaged grains, during the dough stage, were about $3.08-3.99 \%$ in the first products, it ranged higher (4.87-5.21\%) in the second products, Table (3). In the same time, a light difference was detected between the acetonic and water extracts efficiency, $3.08-3.93$ and 3.37- $3.99 \%$, respectively. The same observation was noticed during the mature stage, damaged grains percentages ranged 14.63-19.14 with the extracts and 27.79-31.69 with the oils.

Wormwood acetonic extract (AE) had the highest protection index, 62.4 and $66.5 \%$ in the dough and mature stages, respectively, Table (3). The second rank was occupied by cumin water extract (WE) as $58.8 \& 64.5 \%$, but the least protection $(51.2 \& 56.2 \%)$ was gained when black pepper WE was used. The plant oils, clearly appeared weaker against the bird, the protection index ranged 36.3- 40.5 and 27.4- $36.3 \%$ in the two plant stages, respectively

In the second season, as shown in Table (4), the efficiencies of water extracts of colocynth, coriander, cumin and fenugreek lightly fluctuated in the dough stage and nearly were similar; the protection index ranged 69.2-69.7\%. In the mature stage, this range became wider, 69.7-81.2\%. In addition, the black pepper WE efficiency was, as in the prior season, the weakest, had $51.8-53.7 \%$ only as a protection index.

In this respect, many investigators have reported a repellency phenomenon of some tested compounds against bird species. In USA, first record of two synthetic by EPA contains garlic (effective material) and adding red pepper for bird repellents (Anonymous, 1992). El-Sherbiny et al. (1994) showed that, extracts of coriander, red pepper, camphor, colocynth and wormwood in water had repellent effects on this bird, with protection index as 69.41, 67.00, 66.29, 64.83 and $63.02 \%$, respectively. Omar et al. (1994) found that, plant extract treated grains showed lower palatability to house sparrows than other plant products, as wormwood, colocynth, gum, red pepper and cinnamon are potential sources for plant repellents as they gave more than $90 \%$ repellent. Abdel-All et al. (1995) showed that, datura and oshar ethanolic extracts induced high protection for sorghum grains from crested lark, Galereda cristata attack during the sowing stage. Abdel-All et al. (2002) reported that, blue gum tree leaves and seeds, black pepper, geranium and creater ammi hexanic extracts exhibited repellent effect to house sparrow birds, while only blue gum tree leaves either extracted in hexane or in ethanol exhibited repellent effect to palm dove birds. In USA, water extract of garlic was used as formulation in commercial name Garlic Barrier for bird repellents on crops, vegetables, fruits and flowers (Anonymous, 2003). Garlic oil shows a significant activity as a nontoxic bird repellent for use against crop damaging birds in USA, Arla et al. (2004).

These defensive secondary compounds produced by plant species (i.e. alkaloids, flavonoids, phenolics, glucosinalates, terpenes,...etc.), which are the results of natural selection throughout millions of year, are a potential source of natural repellents and /or natural pesticides that should be exploited by man to protect cultivated crops without the undesirable side effect of synthetic

\section{Head worms:}

Data in Tables (3\&4) reveal that, all plant extracts and oils reduced the population of larvae and pupae of the three considered insects with about 13.0-

Fayoum J. Agric. Res. \& Dev., Vol.22, No.1, January, 2008 
79.1 and $3.8-100 \%$ in the two seasons, respectively. In the first season, $A$. gayneri was the most sensitive insect to the all tested products. Its numbers highly affected and reduced with $23.1-79.1 \%$ whereas this figure was 13.0-42.0 and $30.9-45.8 \%$ for $C$. gnidiella and $P$. simplex, respectively. Also, similar results were obtained in the second season, the reduction ranged 29.7-100\% with the first insect compared with 11.8- 75.2 and 6.9-68.4\% with the other two insects, respectively, Table (4).

Cumin WE had the highest repellent effect on the three insects during the two seasons. It, generally, reduced their numbers with $42.0-79.1 \%$ in the first season and with 68.4-100\% in the second one. In the same time, lupine oil gave the best potential effect; it reduced the larvae and pupae numbers with $81.3 \%$ in case of Autoba and with $71.0 \%$ in Cryptoblabes species. The other products efficiencies varied according to the insect, while the wormwood WE reduced the population of A. gayneri larvae and pupae with $67.0-100 \%$ it reduced that of C. gnidiella and P. simplex with 37.7-44.3 and 42.8-53.2\% in the two seasons, respectively. On the other hand, the black pepper and lupine WE gave the weakest products against all insects. In addition, coriander and Nat 1 oils had the same character against these insects.

Finally, it can be concluded that, certain aromatic extracts and plant oils such as cumin, wormwood, colocynth, Neemix and lupine oil can highly repel female moths of the three insects to lay eggs on sorghum heads causing a best reduction in number of larvae and pupae. While, others can less repel the females causing least reduction such as black pepper, coriander, wormwood oil, fenugreek, Nat 1, coriander oil and lupine.

Awadallah et al. (1984) revealed that onion juice acted as a repellent for Sesamia cretica moths causing a significant reduction in the number of eggmasses. Meisner et al. (1986) sprayed neem seed kernel extract at 0.05- $1.00 \%$ cons. on maize crop against larvae of Ostrinia nubilalis. Soliman and Bleih (1995) found that, onion water extract gave the best control of rice whorl maggot infestation, while, water extracts of wormwood, coriander, chinaberry seeds, garlic and chinaberry leaves were the least effective. They added that coriander water extract gave the highest control of rice stem borer infestation followed by water extracts of chinaberry seeds, wormwood, onion, garlic and chinaberry leaves. Abdel-Rahman (2003) mentioned that, jojoba oil caused 83.84 and $90.82 \%$ mortality at concentrations of 0.5 and $1.0 \%$, respectively to control Liriomyza trifolii larvae in faba bean field. Shalaby et al. (2005) mentioned that, water extracts of coriander, chamomile and chinaberry were more effective in reducing the sugar beet insect populations (Cassidavittata, Scrobipalpa ocellalella, S. littoralis and Pegomia mixta) and in the same time, less effective on the associated predators. Yacoub (2006) stated that, plant extract which are greatly safer than chemical insecticides, proved to be efficient for controlling $S$. cretica and $O$. nubilalis. Among the assayed extracts, Nat 1 , Bioneem and bostachia extract in methanol may be recommended for $S$. cretica control, while Bioneem, lupine extracts in acetone and water may be recommended for $O$. nubilalis control in maize fields.

Fayoum J. Agric. Res. \& Dev., Vol.22, No.1, January, 2008 
REPELLANCY EFFECT OF CERTAIN PLANT EXTRACTS AND... 130

Fayoum J. Agric. Res. \& Dev., Vol.22, No.1, January, 2008 
Fayoum J. Agric. Res. \& Dev., Vol.22, No.1, January, 2008 
Data in Table 5 indicate that, the differences among the water and acetonic extracts were not significant in the grain yield characters when compared with the control. The same differences were significant in the net benefit due to higher acetone price than water. Therefore, the net benefits from sorghum protected from house sparrow bird and worms by using water extracts were higher. The cumin WE gave the highest grain yield/fed (18.60 \& 21.42 ard.), yield increase $(36.51 \& 40.20 \%)$, while the wormwood WE gave the highest net benefit (1137.56 and 1496.24 LE), followed by cumin WE (1044.84 and 1401.56LE) in 2005 and 2006, respectively. In this respect, the plant oils occupied a second rank; the net benefit was 1008.28, 945.56 and 608.44 LE with lupine, coriander and wormwood, respectively.

The research revealed that, using water extracts $(8 \%)$ of wormwood, cumin, coriander, fenugreek, Lupine and colocynth gave a high net benefit and protection for sorghum heads from house sparrow bird and worms.

\section{REFERENCES}

Abdel-Rhahman, S.F. (2003). Damage assessment of certain insects attacking faba bean in the field and store. M.Sc. Thesis, Fac. Agric., Cairo Univ., $121 \mathrm{pp}$.

Abdel-All, S.M.; F. El-Mabrouky and H.I. El-Deeb (2002). The effectiveness of certain plant extracts and conventional insecticides against house sparrow and palm dove birds. Al-Azhar J. Agric. Res., 36 (Dec): 147165.

Abdel-All, S.M.; H.I. El-Deeb; H.A. Zedan and M.B. Wilson (1995). Screening of some wild and ornamental plant extract as bird repellent against certain common bird pest in Egypt. $1^{\text {st }}$ Int. Conf. of Pest Control, Mansoura, Egypt, September.

Ahmed, M.A. (1983). Studies of some insecticidal effects of seven plant extracts against Spodoptera littoralis (Boisd.) and Tribolium confusum (Dnv.). M. Sc. Thesis, Fac. Agric. Cairo Univ.

Anonymous, (1992). Allium sativum (Garlic) EPA, Office of Prevention, Pesticides and Toxic Substances, USA.

Anonymous,(2003). America's \#1 Natural Insect Repellent for Vegetable, Gardens, Flowers and Farms. http://www.Garlicbarrier.com.

Arla, G. H.;S. Zhixing; Z. Shao-Zhong and E. Block (2004). A version of European starlings (Sturnus vulgaris) to garlic oil treated granules: garlic oil as an avian repellent. Garlic oil analysis by nuclear magnetic resonance spectroscopy. J. Agric. Food Chem., 52(8): 2192-2196.

Awadallah, W.H. ; A.F. Lutfallah and Y.H. Fayad (1984). Effect of spraying corn with water extracts of certain aromatic plants on the population of Sesamia cretica_Led. and the main predators in corn fields. Agric. Res. Rev., 62(1): 47-52.

Bruggers, R.L. and P. Ruell (1981). Efficacy of nets and fibers for protecting crops from grains-eating birds in Africa. Crop Port., 1:55-65.

Bullard, R.W. and D.J. Elias (1980). Sorghum polyphenolics and bird resistance. In: J. H. Hulse (ed.), Poly-phenols in cereals and legumes. IDRC, Ottawa, Canada.

Fayoum J. Agric. Res. \& Dev., Vol.22, No.1, January, 2008 
Buntin, D. and J. All (2001). Grain sorghum insects. Summary losses from insect damage and costs of control in Georgia. http://www.ent.uga.edu/IPM/slol/grain sorghum.htm

Crocker, D.R. (1990). Plant secondary compounds-A basis for new avian repellent. Vert. Pest Conf., 14:339-342.

El-Deeb, H.I.H. (1990). Effect of certain compounds as bird repellants to protect field crops under different conditions. Zagazig J. Agric. Res., 17(5B): 1701-1707.

El-Rawy, A.M. (2004). Semi-looper worm, Autoba (Eublemma) gayneri (Roth.) (Lepidoptera: Noctuidae) as an insect pest on maize in Egypt. Ph.D. Thesis, Fac. Agric., Cairo Univ.,156 pp.

El-Sherbiny, A.H.; A.M. Omar; A.G. El-Sisi and M.A.A. Hewady (1994). Natural botanical extracts as repellents for the house sparrow, Passer domesticus. II. Efficacy under rice field condition. Annals Agric. Sc. Moshtohor, 32(2): 1053 -1064.

Fellows, L.E. (1979). Plant secondary compounds as a chemical defense in bird problems in agricultural. (E.N. Wright ed.):188-195.

Fitzwater, W.D. (1982). Getting physical with birds. In bird control in food plant (Baur, F. J. and Jackson, WB., eds.). The American Association of Cereal Chemists, St. Paul, Minnesota : 31-44.

Freedman, B.; J. Nowak and W.F. Kolek (1979). A bioassay for plant derived pest control agent using the European corn borer. J. Econ. Entomol. 72:45-54.

Inglis, I.R. and A.J. Isaacson (1987). Development of simple scaring device for woodpigeon (Columba palumbus). Crop Prot., 6(2):104-108.

ManiKowski, S. and B. Treca (1982). Mesure de 1'impact des oiseaux granivores sur les cultures en Afrique de 1' Ouest. FAO/UNDP Internal Report RAF/81/022.

Manikowski, S. and F. Billiet (1983). Dégâts d' oiseaux à 1' Office du Niger au Mali en 1982. FAO/UNDP Internal Report RAF/81/022.

Martin, I.R. and J.J. Jackson (1977). Field testing a bird repellent chemical on cereal crops. Test Methods for Vertebrate Pest Control and Management Materials, ASTM-STP, 623:177-185.

Meisner, J.; M.V. Melamed; S. Yatham and K.R.S. Asher (1986). The effect of azadirachtin on larvae of the European corn borer, Ostrinia nubilalis. Zeitschrift-fur, Pflanzenkran-Kheiten und Pflanzerschutz, 93 (6):585589.

Omar, A.M.; A.H. El-Sherbiny; A.G.El-Sisi; M. Abdel-Moaty and A.A. Abdel-Hafez (1994). Natural botanical extracts as repellents for the house sparrow, Passer domesticus. 1. Efficacy under semi-natural conditions. Annals Agric. Sc. Moshtohor, 32(2):1043-1051.

Shalaby, G. A.; A. M. Bassyouni and M. M. Metwally (2005). Effectiveness of certain plant extracts against insect pests and predators in sugar beet fields. Egypt. J Agric. Res., 83 (3): 1191- 1198.

Snedecor, G. W. and W. G. Cochran (1981). Statistical Methods. Seventh Ed., Iowa State Univ. Press, Ames. Iowa, USA.

Soliman, A.M. and S.B. Bleih (1995). Effect of certain natural plant extracts on the rice stem borer Chilo agamemnon Bles. and rice whorl maggot Hydrellia prosternalis Deeming infestation. Egypt. J. Agric. Res., 73(4):993-1000.

Fayoum J. Agric. Res. \& Dev., Vol.22, No.1, January, 2008 
Yacoub, S.S. (2006). Efficacy of some plant extracts in controlling Sesamia cretica Led. and Ostrinia nubilalis (Hubn.) in maize fields. Ph. D. Thesis, Fac. Agric. Benha Univ., 309pp.

التأثير الطارد لبعض المستخلصات والزيوت النباتية لعصفور النيل الدورى ويعض الحشرات التى

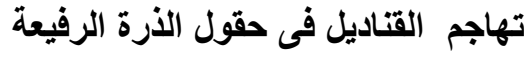

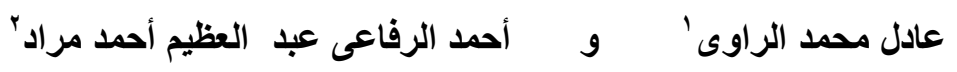

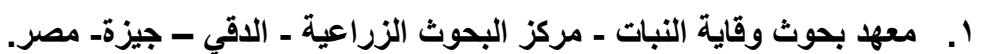

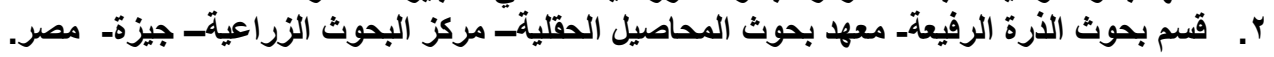

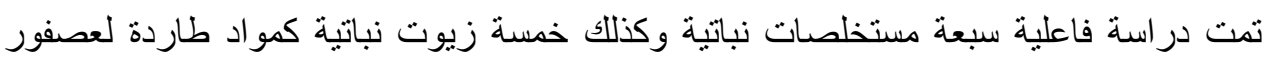

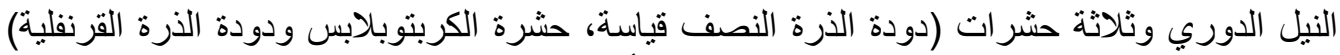

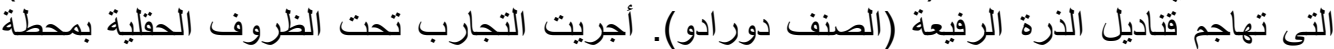

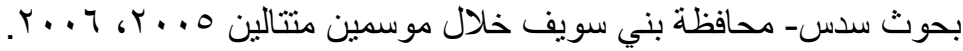

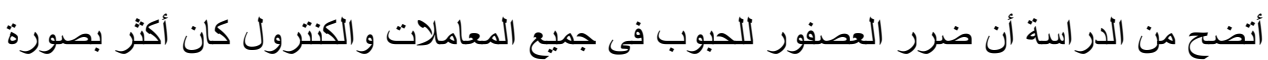

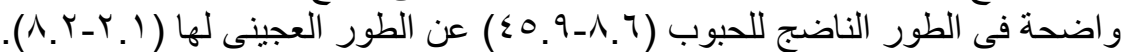

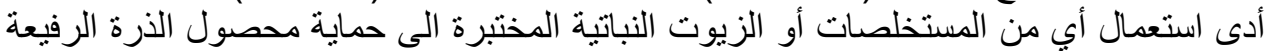

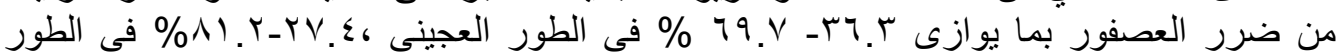

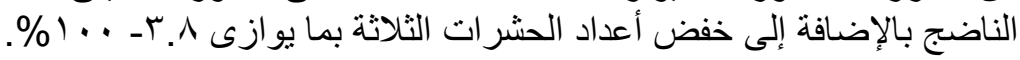

أظهرت المستخلصات فعالية أكثر ضد العصفور فئ الطور الطور الناضج للمحصول عنه فى الطور العجينى بينما حدث عكس ذلك مع الزيوت.

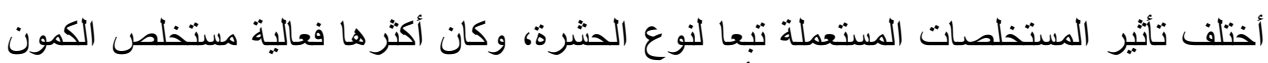

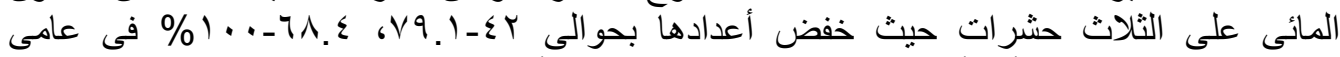

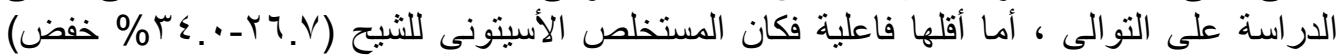

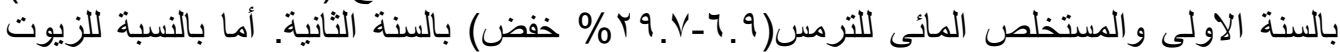

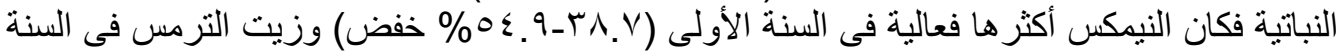

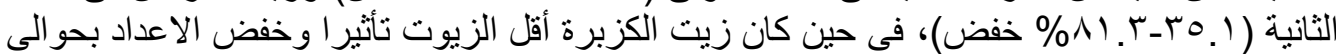
. $\%$ \%

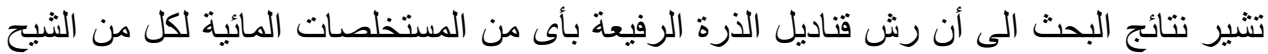

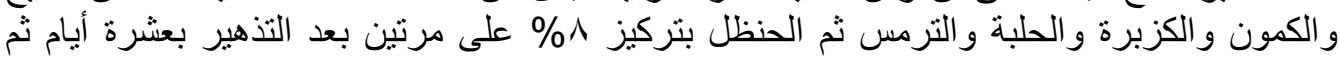
بعده بـ مب يوم قد قلل ضرر الطيور والاففات الحشرية التى تهاجم القناديل مما أدى إلى زئى زيادة العائد

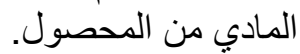

Fayoum J. Agric. Res. \& Dev., Vol.22, No.1, January, 2008 